\title{
The Impact of Information Communication and Technology Utilization on the Financial Performance of Microfinance Institutions in Rwanda Case Study: Reseau Interdiocesain De Microfinance (Rim) Ltd, Rwanda (2011-2015)
}

\author{
Jean Bosco Harelimana ${ }^{1, *}$ \\ ${ }^{1}$ Institut d'Enseignement Superieur de Ruhengeri, Musanze, Rwanda \\ *Correspondence: Institut d'Enseignement Superieur de Ruhengeri, P.O.B. 155 Musanze, Rwanda. E-mail: \\ harelijordan@yahoo.fr
}

Received: February 20, 2017 Accepted: March 7, 2017 Online Published: April 27, 2017

doi:10.5430/mos.v4n2p13

URL: https://doi.org/10.5430/mos.v4n2p13

\begin{abstract}
The study analyzed the impact of ICT utilization on the financial performance of microfinance institutions in Rwanda with case study of Réseau Interdiocesain de microfinance (RIM) Ltd undertaken within 5 years (2011 -2015). The study adopted the use of descriptive survey using both qualitative and quantitative methods for a total sample size of 132. Purporsive and simple random simpling was used for this purpose. Primary and Secondary data were collected and thene analyzed using SPSS version 16.00. The study found that ICT has been introduced and used about 5 years and above. The study found that ICT impact firstly on financial sustainability and profitability (65.8\%), secondly on financial efficiency and productivity (23.7) and finally on portfolio quality (5.3\%). ICT utilization have a high influence to the RIM Ltd.'s financial performance compared to the previous situation.

The correlation results imply that ICT usage has a positive impact on financial sustainability and profitability as they move in the same direction $(\mathrm{R}=0.502)$. The strength of the impact was found to be low due to the low investments in ICT among microfinance institutions.

Keywords: ICT; Internet banking accessibility; branch networking; digital financial services; clients' satisfaction; microfinance institutions; computerized accounting system; microfinance financial performance indicators
\end{abstract}

\section{Introduction}

Today, global poverty and malnourishment rank among the largest humanitarian problems in the world. An estimated 805 million, or $11.3 \%$ of the world's population, were classified as chronically undernourished in 2012-2014 (FAO, 2014). This problem is the most pronounced in Sub-Saharan Africa where $23.8 \%$ of the population is undernourished. Poverty ranks as the principal reason for malnourishment (Riggins \& Weber, 2016). To enhance international development, the United Nations (UN) announced the millennium development goals, aimed to eradicate poverty by 2015 (Arifujjaman \& Rahaman, 2007). To achieve this goal, the UN counts to the Microfinance as one and sure way to fight against poverty as well as the microfinance industry is the form of financial development that is now being considered as one of the most important and an effective mechanism for poverty alleviation. The emergence of microfinance in the past three decades is viewed as a critical component in the fight against global poverty (Mosley, 2001). Microfinance is defined as the provisioning of financial services to poor or low-income clients, including consumers and entrepreneurs who would otherwise not be served by traditional financial institutions (Ledgerwood, 2000). According to Mosley (2001), microfinance makes a considerable contribution to the reduction of poverty through its impact on income and also has a positive impact on asset level. That's why, the UN, declared 2005 as the International Year of Microcredit.

Microfinance institutions are the main financing sources for the poor and low income households around the world. They provide financial services to this world's poor in hopes of moving individuals and families out of poverty. 
These institutions provide financial services to the poor who are excluded by formal financial systems, to enable them sustain living and engage in economic activity through entrepreneurial activity and small business which together have impacts on country economic developments (Kipesha, 2013).

In this regard, Microfinance industry serves as an umbrella term that describes the provision of banking services by poverty-focused financial institutions to poor parts of the population that are not being served by mainstream financial services providers (Sehgal, 2008). MFIs play also a very important role in the economy. More precisely, MFIs have a two-fold mission which is social and economic by helping the customers to have active financial lives, intermediate a large part of their income, seek ways to save, borrow and insure and focus first on day to day needs (Bernd, 2007).

To achieve this mission, the microfinance sector, as for any other financial institutions, has a great task to adopt and adapt the information, Communication and Technology (ICT) to improve its products and services as well as today's business environment is extremely dynamic and experience rapid changes as a result of technological improvement, increased awareness and demands Banks to serve their customers electronically (Agboola, 2001). In fact, ICT has been also shown to have some impact on poverty at the micro, meso and macro levels (Arifujjaman \& Raham, 2007). Low ICT capabilities diminish the ability to use financial services to reduce poverty in developing areas. Nowadays, the Banking industry operates in a complex and competitive environment characterized by these changing conditions and highly unpredictable economic climate in the World in general and in Africa in particular (Agboola, 2001).

That's why financial institutions, in which MFIs occur, invest their time, human resources and huge sums of money in ICT, having their products and services basically supported by it. Bidley (2000) argues that Information and communication technology has brought a complete paradigm shift on the banks performance and on the customer service delivery in the banking industry. In a bid to catch up with global development, improve the quality of customer service delivery, and reduce transaction cost, banks invest heavily in ICT and widely adopt ICT networks for delivering a wide range of value added products and services. The aim target of this study is to assess the impact of this investment in ICT on financial performance of microfinance institutions in Rwanda, with a case study of RIM Ltd.

The Microfinance is maturing in part due to the adoption of information and communication technologies (ICT). Thus, because in present day banking, total automation of banking operations is an imperative need for all banks and microfinance institutions to enhance convenience by extending access to customers residing outside the branch network and creating opportunities for effective cross-selling, to attract more customers, to provide efficient and quality services, and survive in the emerging new competition, apart from the profit motive which is the primary objective of the banks (Juma, 2012). Competition forces MFIs to invest in ICT to realize increased efficiency and quality service delivery, to mitigate costs and increase efficiency to achieve customer satisfaction and to boost their profitability (Riggins \& Weber, 2016).

In one hand, a sizeable number of studies on relationship between ICT investment and financial performance undertaken in banking sector in general and microfinance in particular, revealed that firms using ICT performed better compared to those that were reluctant to adopt it (Bidley, 2000). They revealed also that ICT investment led to reduction in costs and improved performance. In a other hand, although, others studies revealed that some microfinance programs, even though they invest in ICT, find little success either in reaching the poorest individuals (social performance), either in reaching the financial performance goals : loan portfolio, efficiency, productivity, profitability, and sustainability) or in focusing on one of these two elements in disfavor of another. Thus, these some and not at least facts reveal that to invest in ICT is not always and everywhere a success guarantee of financial performance and of efficient and productive management. Then, the crucial problem is how to make evidences of the impact of ICT utilization on financial performance in MFIs which invest in it.

In Rwanda and banking sector, ICT in now-a-days is not a matter of convenience but a survival factor. If traditional banks, mostly public sector banks, do not transform their business by introducing ICT in its all aspects, their survival will become difficult (Keivin et Al., 2011). That's why, the potential customers and big companies are shifting their accounts from traditional banks (not fully computerized) to E-banks (fully computerized and provide different e-channels). Accordingly, a number of MFIs had already invested in ICT but they are still operating in the old traditional way BNR (2015). RIM Ltd is one of these MFIs which introduced ICT in its services and products in about five years ago after a long period of traditional and manual management and its abuses. Then, the problem is to know in which extent RIM Ltd invested in ICT? How the RIM Ltd.'s ICT utilization enhanced its management, improved its services and products quality and influenced its financial performance? How the ICT remains in RIM Ltd an efficient and affordable tool to fight against misappropriation of cash, frauds, mismanagement, windows 
dressing phenomena, and improve management? Does exist a relationship between ICT utilization and financial performance realized by RIM Ltd in this five last years?

This study finds its motivation in this higher need for evidences on the impact of ICT adoption and usage on financial performance of Microfinance institutions in Rwanda in general and in RIM Ltd especially. These evidences will act as a benchmark for Microfinance institutions in Rwanda, which have not adopted ICT in their business operations. They will also act as a push factor for policy making regarding ICT in Microfinance Institutions to enable utilization of the benefits associated by ICT uses. Considering RIM Ltd as case study and by focusing in it especially on the impact of ICT on Loan repayment (portfolio quality), efficiency and productivity use of resources, profitability and financial sustainability of MFIs, this research examines how ICT is changing the microfinance industry, how, by its usage, many clients are satisfied for the services et products rendered to them, how well the MFIs collect their loans, how MFIs are profitable enough to maintain and expand their services without continued injections of subsidies and how well sustainable they are and efficiently they control its operating costs.

Hypotheses to be verified are the following:

1. Internet banking accessibility, branch networking, digital financial services, computerized accounting system and clients satisfaction are the determinants of ICT utilization in Réseau Interdiocésain de Microfinance RIM Ltd.

2. Portfolio quality, financial efficiency and productivity, financial sustainability and profitability are indicators of financial performance of RIM Ltd.

3. The determinants of ICT explain significantly with the financial performance indicators of RIM Ltd.

\section{Objectives}

The main objective of the study is to assess the Impact of ICT Utilization on financial performance of Microfinance Institutions in Rwanda specically we have the following objectives:

- To assess the determinants of ICT utilization in Réseau Interdiocésain de Microfinance (RIM) Ltd.

- To analyze the indicators of financial performance before and after ICT utilization by RIM Ltd.

- To measure the relationship between the determinants of ICT Utilization and financial performance indicators of RIM Ltd.

\section{Literature Review}

ICT is "the scientific, technological and engineering disciplines and the management techniques used in information handling, processing and disseminating; their applications; computers, networking and communication and their integration with men and machines; and associated social, economic and cultural matter" (Kimani, 2014). It is an umbrella term that includes any communication device or application, encompassing: radio, television, cellular phones, computer and network hardware and software, satellite systems and so on, as well as the various services and applications associated with them, such as videoconferencing and distance learning (Agboola, 2001). According to Freeman et Al., (2010), ICT is a field of work and study that "includes technologies such as desktop and laptop computers, software, peripherals, and connections to the Internet that are intended to fulfil information processing and communications functions".

Electronic banking is the provision of banking products and services, including electronic payments, through electronic channels. According to Keivin et Al., (2011), it is an umbrella term for the process by which a customer may perform banking transactions electronically without visiting a brick-and-mortar institution. For Daniel \& Wilson (2003), it refers to several types of services through which a bank's customers can request information and carry out most retail banking services via computer, television or mobile phone. Accordingly, Berger \& Wharton (2003) describe it as an electronic connection between the bank and customer in order to prepare, manage and control financial transactions.

Clients satisfaction is a term frequently used in marketing. It is a measure of how products and services supplied by a company meet or surpass customer expectation. For Gustafsson et Al., (2006), customer satisfaction is defined as a customer's overall evaluation of the performance of an offering to date. This overall satisfaction has a strong positive effect on customer loyalty intentions across a wide range of product and service categories. 
A system is a set of interdependent elements that together accomplish specific objectives. Romney \& Steinbart (2009) defined an information system as an organized means of collecting, entering, and processing data and storing, managing, controlling, and reporting information so that an organization can achieve its objectives and goals. Gelinas et al., (2005) emphasized that, information system has the following components: Goals and objective, Inputs, Output, Data storage, Instructions and Procedure, Users, Control and Measures. Accounting system as an "information system is a man-made system that generally consists of an integrated set of computer-based and manual components establish to collect, store, and manage data and to provide output information to users" (Gelinas et al., 2005).

Computerized Accounting Systems is a computer based system which combines accounting principles and concepts as well as the concept of information system to record, process, analyses and produce financial information to its users for making economic decisions. (Gelinas et al., 2005). For Baren, (2010) the use of computers is time-saving for businesses and all financial information for the business is well organized so that the Computerized Accounting Systems are important to businesses in various ways such as time and Cost Savings, organization and accuracy, storage and speed and easy distribution of financial information.

Microfinance, according to Otero \& Rhyne (1999) is "the provision of financial services to low-income poor and very poor self-employed people".

Financial performance is a measure of how well a firm can use assets from its primary mode of business and generate revenues (Cull et $\mathrm{Al}$., 2007). This term is also used as a general measure of a firm's overall financial health over a given period of time and it is one of major indicator of organizational performance. For Zeller et Al., (2002), financial performance can be defined as the accomplishment of a given task that is measured using predetermined standards of accuracy, completeness, efficiency and effectiveness.

There are many studies carried out on impact of ICT utilization on financial performance of MFIs. In this part, the study presents some of studies related to the topic.

Kimata (2013) did a study on effects of ICT on the financial performance of deposit taking SACCOS (DTS) in Nairobi County. The study used a descriptive survey to find out how ICT impacts on customer services system and reduction in operational costs. The population of interest was all the 44 deposit taking Saccos in Nairobi County. Secondary data was sourced from the Sacco's annual financial reports and Sacco Societies Regulatory Authority (SASRA) supervisory reports. The data covered the period 2008 to 2012. Data analysis involved reducing accumulated data to manageable levels, developing summaries, looking for patterns and applying statistical techniques. The study established that ICT adoption were a major contributor to financial performance of DTS.

Kipesha (2013) did a study on the impact of ICT adoption on efficiency and financial sustainability of microfinance institutions in Tanzania. The study used data envelopment analysis (DEA) model to estimate technical efficiency and regression analysis model was used to test for association and cause and effect between ICT with efficiency and financial sustainability. The study reports the presence of positive but weak association and insignificant course and effect between ICT usage with efficiency and financial sustainability. ICT adoption was found to have a positive correlation with efficiency and financial sustainability in microfinance institutions. The correlation results imply that ICT usage has a positive impact on efficiency and sustainability as they move in the same direction. The strength of the impact was found to be low due low investments in ICT among microfinance firms.

Kamau (2014) carried out a study on the effect of ICT adoption on the financial performance of microfinance institutions in Kenya. The study did a descriptive survey to find out the factors that influence ICT adoption on financial performance of microfinance institutions in Kenya. The study carried out tests on the effects of ICT adoption on the financial performance of MFIs for the period 2008-2012. Primary data was collected through a questionnaire. An analytical model was developed to determine the strength of the relationship between variables. Analysis of the data showed that there was a positive correlation between ICT adoption and financial performance of MFI's.

Musa et Al., (2012) conducted a study to assess the impact of investment in information and communication technology on performance and growth of microfinance institution in Uganda. Performance is measured as a change in total factor productivity and growth as change in scale of operation. Two level growth models were used to determine the impact of investment in information and communication technologies on total factor productivity and scale change trajectories of individual microfinance firms. Results indicate that about $18 \%$ variation in performance and $19 \%$ variation in growth across firms were due to investment in information and communication technologies. They concluded that the shrinking customer base, decreasing marginal returns, and increased competition are 
necessitating selecting optimal input-mix and investment in information and communication technology by microfinance institutions in Uganda. This will ensure providing service at lower cost and sustainability and microfinance institutions in Uganda.

Muteteri (2015) made a study on the contribution of E-banking towards banking on performance of banking Institutions in Rwanda. The study used a descriptive method based on qualitative and quantitative approach. Secondary data was used to collect information from financial statements and records. As results, it was established that Electronic banking system like ATM, Pay direct, electronic check conversion, mobile telephone banking and E transact has a great impact on bank performance because they increase profitability, reduce bank cost of operations, and increase bank asset and bank efficiency. It is revealed that there is a significant relationship between E banking and Performance of bank of Kigali in Rwanda.

Most studies locally and globally have shown that there is a positive relationship between ICT investment and financial performance of firms. It has shown that the ICT utilization impacts more on firms' costs reduction, increased sales, and profitability enhanced efficiency and sustainability. This also supports the assumptions held by the above theories on the importance of ICT in enhancing financial performance. However, among the extensive researches done on ICT and financial performance; little focus has been placed within the context of microfinance institutions in Rwanda. Thus, this justifies the need to investigate the impact of ICT utilization on financial performance of microfinance institutions in Rwanda.

\section{Methodology}

This section summarized dimensions of the research, tools and techniques and methods used to achieve the research objectives.

Data collection: Data were collected, as primary data, using observation, interview and questionnaire techniques and secondary data. A Self-administered questionnaire was designed for 132 members of RIM ltd in collection of primary data and the technique of documentation for secondary data was used. Consequently, the sample in this study has been chosen purposively based on gender, age and working experience with RIM Ltd using Alain Bouchard's formula with confidence interval of $95 \%$ and a permissible margin error of $10 \%$. The total population is categorized into two: The first category (Staff) of population size equals 162 and the second (clients) equals 150493 with the sample size 36 and 96 respectively. The total sample size is 162 .

Data analysis: To assess the impact of ICT utilization of financial performance of microfinance institutions, the researcher considered both quantitative and qualitative data which were coded, summarized and presenting using SPSS. Apart from descriptive statistics of Mean, Frequency and percentages on the characteristics of the respondent, regression analysis was used to measure and predict the relationship between the predictor variables and the dependent variable. The general form of the model was as follows: $Y=\alpha+\beta_{1} X_{1}+\beta_{2} X_{2}+\beta_{3} X_{3}+\beta_{4} X_{4}+\beta_{5} X_{5}+e$

Where, $\mathrm{Y}=$ financial performance, $\mathrm{X}_{1}=$ Internet banking accessibility, $\mathrm{X}_{2}=$ branch networking, $\mathrm{X}_{3}=$ Digital financial services, $\mathrm{X}_{4}=$ software and computerized accounting system, $\mathrm{X}_{5}=$ clients satisfaction and $\alpha$ is constant and $\beta_{1}, \beta_{2}, \beta_{3}$ and $\beta_{4}$ are coefficient to estimate, and e is the error term.

Since the study intends to assess whether ICT utilization has any relationship with the financial performance of RIM Ltd, which is the dependent variable, the most commonly used relational statistic is correlation ( $\mathrm{r}$ ) and it is a measure of the strength of a relationship between two variables, but not causality. Beside this equation, the correlation coefficient was calculated using the SPSS. The statistical method helped in computing the correlation between ICT (X) and financial performance (Y) of RIM Ltd. Pearson's correlation coefficient was used as a statistical measure of the strength of a linear relationship between paired data.

\section{Results, Discussion and Findings}

\subsection{Assessment of ICT utilization in RIM Ltd}

The study intended to assess the Impact of ICT utilization on financial performance of microfinance institutions in Rwanda by determining the ICT determinants and its relationship to the financial performance indicators of RIM Lt during the period of study.

\section{- $\quad$ Time and extent of introduction of ICT in RIM Ltd}

To understand how long and with which extent ICT has been introduced and used in RIM Ltd, the staff respondents 
were separately asked on the ICT introduction period while the clients respondents were asked to certify if, considering the services and products they received from RIM Ltd, they find the marks of ICT utilization. The details of findings are shown in the figure below:

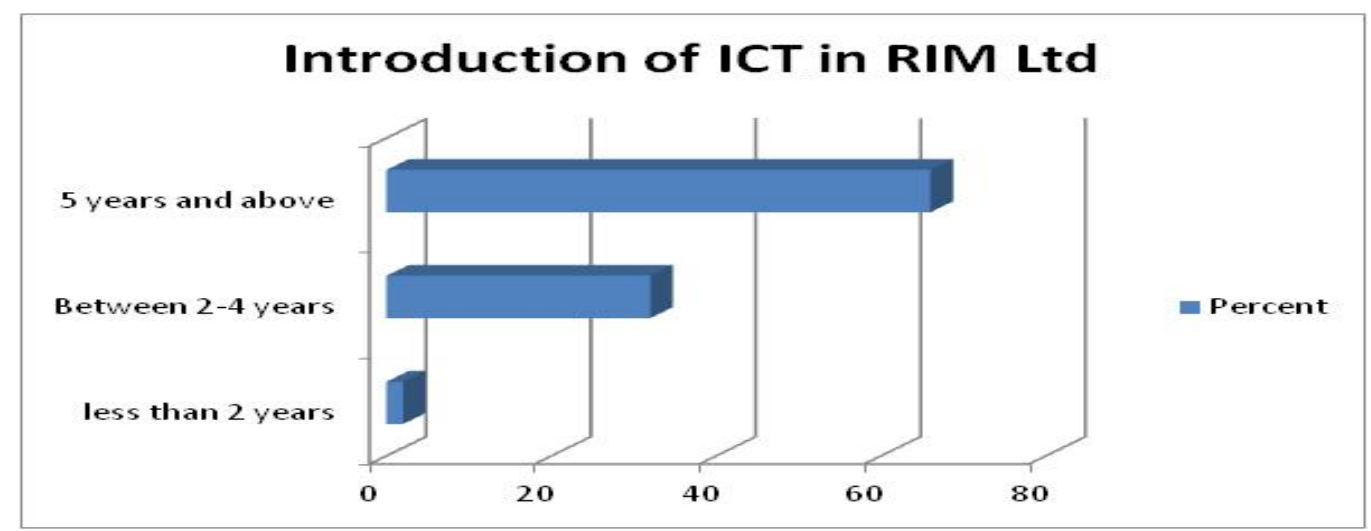

Figure 1. ICT introduction period in RIM Ltd

Source: Primary data, January 2017

On one hand, the findings revealed that, concerning the time ICT has been introduced in RIM Ltd, $65.8 \%$ of sampled staff testify that ICT in RIM Ltd has been used about 5 years and above. $31.6 \%$ of them state a period between 2 and 4 years and $2.6 \%$ of them affirm the time less than 2 years. On the other hand, about $40.6 \%$ of clients' respondents strongly agree and $51.0 \%$ of them agree that, considering the services and products they received from RIM Ltd, RIM Ltd has already introduced ICT for a long time back of and confirm the utilization of it in its usually services and products directed to the customers. This is for RIM Ltd a good index in conformity with Keivin et Al. (2011) who specified that in banking industry, ICT in now-a-days is not a matter of convenience but a survival factor. If traditional banks, mostly public sector banks, do not transform their business by introducing ICT in its all aspects, their survival will become difficult.

\section{- Determinants of ICT utilization in RIM Ltd}

In banking sector, ICT uses the newest technologies to process and communicate information. In these technologies, researcher took electronic banking accessibility, branch networking, digital financial services, software and computerized accounting system as determinants of ICT in RIM Ltd.

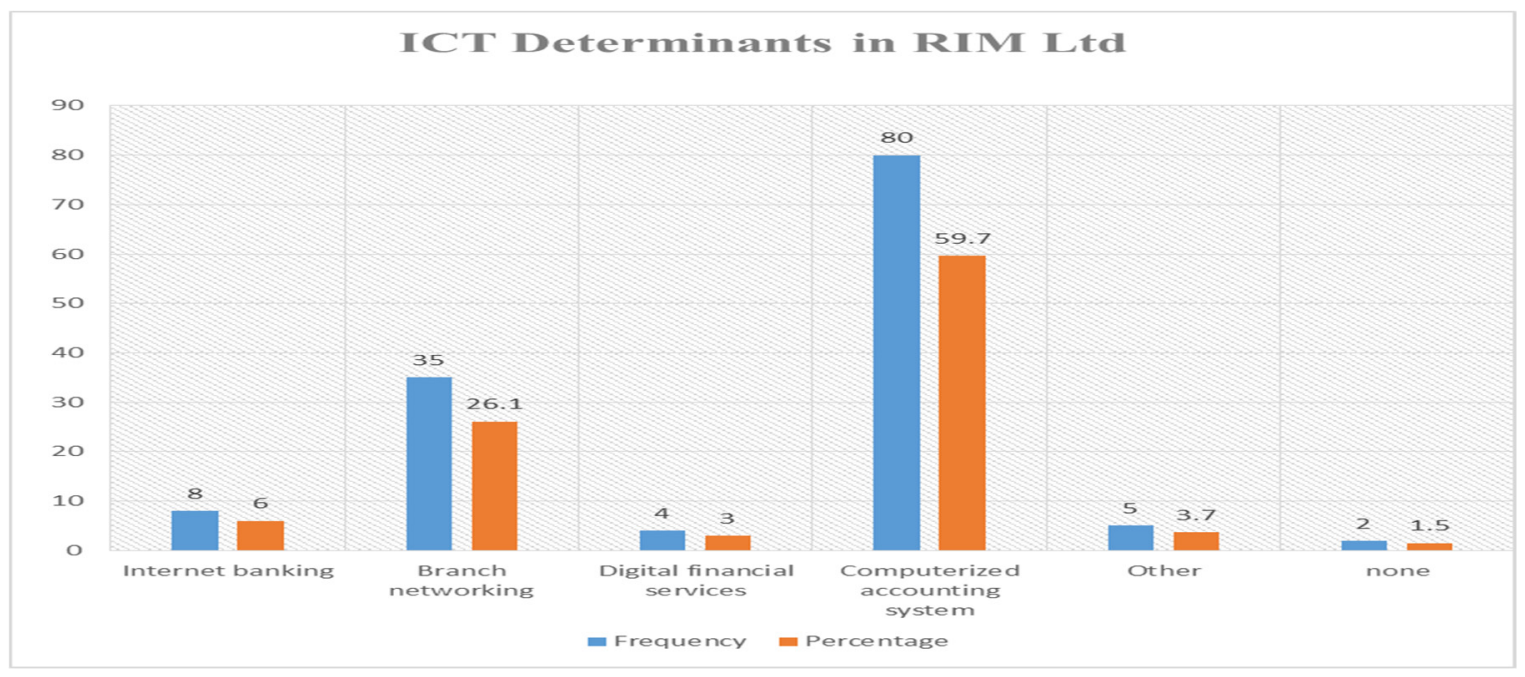

Figure 2. Comparison of ICT Determinants Used in RIM Ltd

Source: Primary data, January 2017 
It is observed that software and computerized accounting system (59.7\%) and branch networking (26.1\%) are the most used determinants of ICT in RIM Ltd. The others such as internet banking (6.0\%), digital financial services (3\%) and others (3.7) remain insignificants and are simply not used in RIM Ltd. These results shows that RIM Ltd did not mostly invested in ICT unless in two of its components. This is not a good index for RIM Ltd and should impact negatively on its competition with others financial institutions in the country and on its financial performance. The results on ICT determinants are in closeness with Riggins \& Weber (2016) who stated that competition forces MFIs to invest in ICT to realize increased efficiency and quality service delivery, to mitigate costs and increase efficiency to achieve customer satisfaction and to boost their profitability.

- Degree of use of determinants of ICT in RIM Ltd

To assess if in RIM Ltd the internet banking is accessible, we present the results from respondents. These results confirm that $63.2 \%$ agree RIM Ltd has the internet banking accessibility while $26.3 \%$ others disagree for that option whereas 65.6 of clients respondents disagree and are not sure for the internet banking accessibility.

The findings shows $42.5 \%$ confirm the internet banking accessibility in RIM Ltd whereas $57.5 \%$ disagree for this option. We can conclude that the staff are sufficiently informed on internet banking accessibility in RIM Ltd while the clients are not. This is an indicator that this determinant of ICT is insufficiently used in RIM Ltd in the manner that it is not clearly visible in the services and products the clients receive in RIM Ltd. These results are enough confirmed by the findings below on the kind of internet or electronic banking used in RIM Ltd's services and products.

\section{- Extent use of electronic banking services and products in RIM Ltd}

Asked to identify exactly what kind of electronic banking services and products RIM Ltd offers to its customers, the respondents chose only 2 as follows:

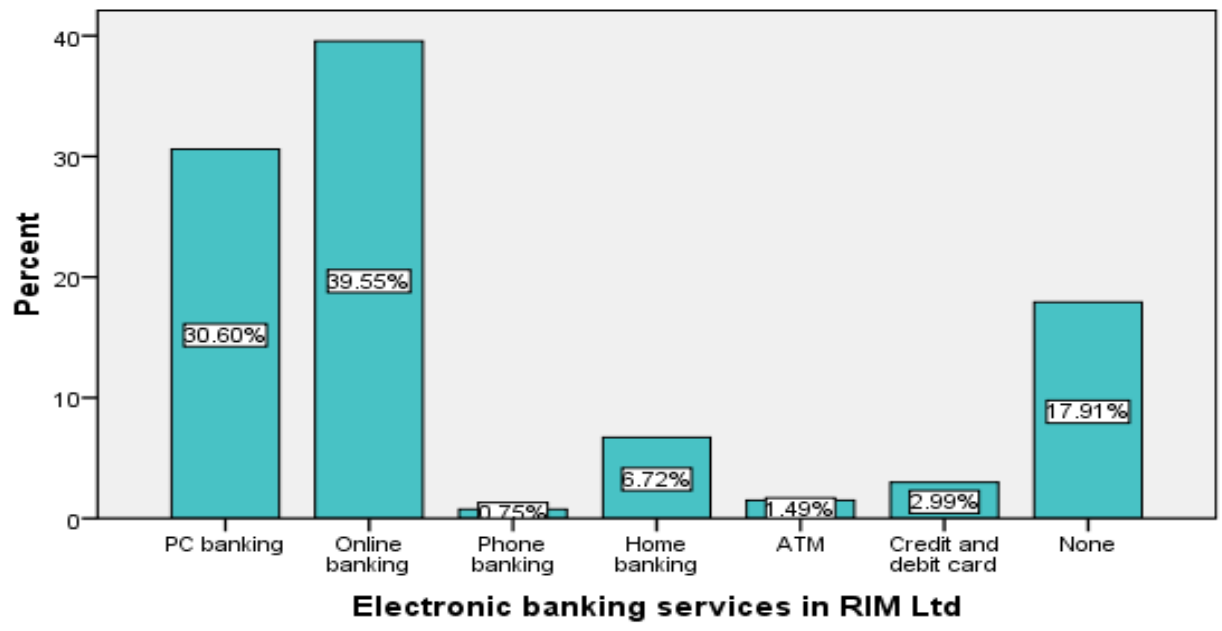

Figure 3. Electronic Banking Services in RIM Ltd

From the information presented, it is important to notice that a significant portion of respondents $(17.9 \%)$ certify that among these mentioned electronic banking services, none of them is used in RIM Ltd. That assertion explains the reason why the internet banking accessibility was relatively and lowly used in RIM Ltd. In each category, 


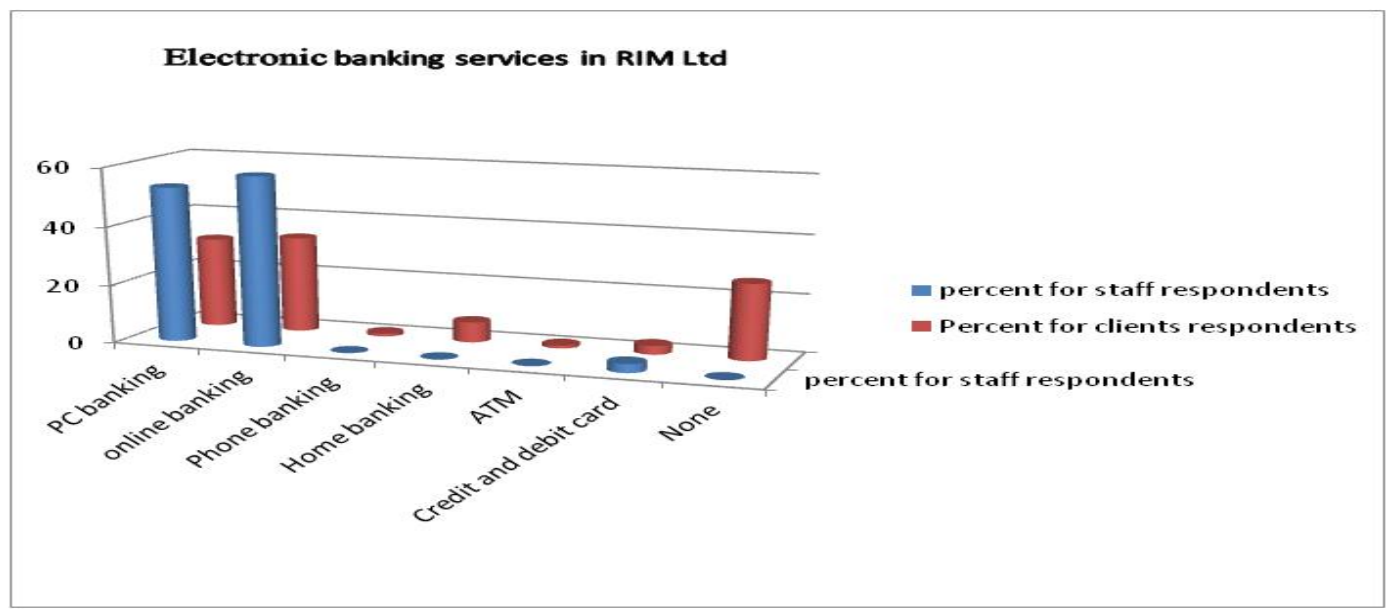

Figure 4. Electronic Banking Services in RIM Ltd by Each Category of Respondents

Source: Primary data, January 2017

The figure shows that the staff are sufficiently informed on internet banking accessibility in RIM Ltd while the clients are not.

Although, at the different level, both staff and clients agree that PC banking and online banking are again the most characteristics of electronic banking usage in RIM Ltd. The others occupy the insignificant place or they are virtually no introduced in RIM Ltd. The results confirm also the fact that RIM Ltd did not invest enough in ICT utilization which contribute to the RIM Ltd's growth handicap in future. This discussion is referring on Keivin et Al. (2011) who stated, about the electronic banking, that the potential customers and big companies are shifting their accounts from traditional banks (not fully computerized) to E-banks (fully computerized and provide different e-channels). That is why the electronic banking accessibility is most important even though it involves consumers using the internet to access their bank account and to undertake banking transactions.

- Extent use of branch networking in RIM Ltd

To assess if RIM Ltd uses the branch networking and in which extent, see the figure below :

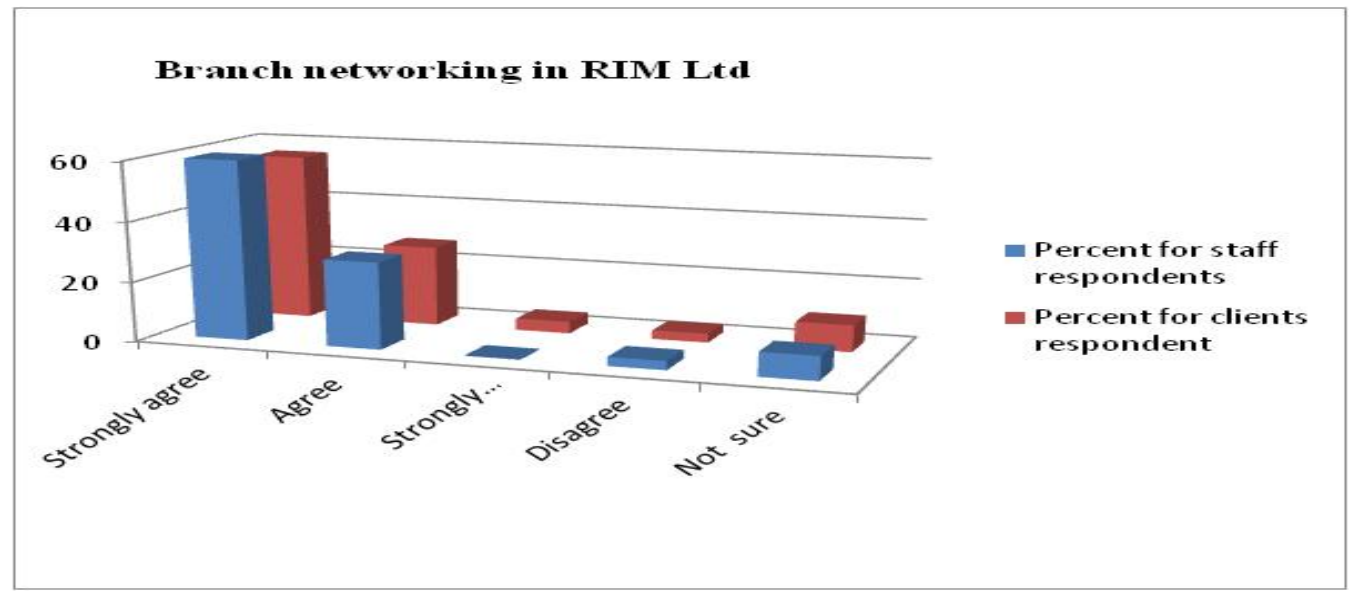

Figure 5. Branch Networking in RIM Ltd

Source: Primary data, January 2017

The findings show that on one hand, $60.5 \%$ and $28.9 \%$ respectively strongly agree and agree that there is a branch networking in RIM Ltd. Few are ones who disagree (2.6\%) and say to be not sure (7.9\%). And also $56.2 \%$ and $27.1 \%$ of clients' respondents respectively strongly agree and agree that ICT system of branch networking exists in RIM Ltd. $4.2 \%$ and $3.1 \%$ of them respectively strongly disagree and disagree the existence of branch networking in RIM Ltd 
while $9.4 \%$ of them say to be not sure for that. The analysis show that the system of branch networking is already exist in RIM Ltd and confirm exactly the results above. RIM has invested hugely in branch networking and this is a good index in conformity of TSB (2014) who argued that the future of banking lies in branches and technology-enabling customers to bank where they want, how they want and when they want.

\section{- Extent use of digital financial services}

The Digital Financial Services (DFS) includes mobile financial services (MFS) used to access banking services and execute financial transactions. It includes the broad range of financial services accessed and delivered through digital channels, including payments, credit, savings, remittances and insurance, mobile phones, ATMs, Point of Sale (POS) terminals, Near Field Communication (NFC)-enabled devices, chips, electronically enabled cards, biometric devices, tablets, phablets and any other digital system (Keivin et al., 2011).

To assess the use of DFS, the reseacher found that $59.7 \%$ of all respondents disagree any existence of digital financial services in RIM Ltd whereas $29.1 \%$ of them are not sure for this option. In clients' respondents, $56.2 \%$ disagree while $33.3 \%$ are not sure. In staff category, $68.5 \%$ disagree while $18.4 \%$ are not sure for the affirmation. This actual situation of RIM Ltd face to digital financial services invites it to review its services and products strategies, otherwise it should be out time. If RIM Ltd want to offer genuine competition in the future, it must think strongly to its ability to meet the actual customer demand in conformity with TSB (2014) which argue that for bank, this ability to meet that customer demand is crucial because the customers are adopting mobile and digital banking at a pace we have never seen before.

The findings on digital financial services lead the study to argue that in RIM Ltd there is no use of digital financial services. This is not a good index because, in reference on GATERA (2015)'s study on the Digital financial services and savings of Microfinance Institutions in Rwanda with a case study of COPEDU Ltd and on BNR (2015) financial stability report, it is shown that in Rwanda, the mobile banking technology is playing a big role to enhance electronic payments and promote the access and usage of financial services and products by increasing the usage of mobile financial services and E-banking products (BNR, 2015). Nowadays, the mobile financial services like Mobile money stay in Rwanda the fastest; easiest and most affordable way to send money to anyone; anywhere in Rwanda which attract many users especially from the remote area. Today, many banks and other financial institutions have already invested in digital financial services. Accordingly, smart cash cardholders from seven banks out of eight banks (97\% of the smartcards market) can pay at merchants POS in the Rwanda while Visa Cards are accepted at all POS. With regard to interoperability in mobile payment, three MNOs have partnered with some banks to enable bank account to e-money account transfers for the same client and vice versa. Further, fully interoperable transfers between bank account and e-money account of different clients are enabled between one bank and one MNO (BNR, 2015).

\section{- Use of software and computerized accounting system in RIM Ltd}

About $80.2 \%$ of clients respondents agreed that software and computerized accounting system is used in RIM Ltd whereas $89.4 \%$ of staff's respondents also confirmed this use of it. The system of computerized accounting system is highly used in RIM Ltd, which justifies a good and rapid services oriented to the customers as reported. In five years ago, RIM Ltd utilized "Perfect" as software. This contributes surely on the financial performance of RIM Ltd in accordance with Baren (2010) who argued that the use of computers is time-saving for businesses and all financial information for the business is well organized so that the computerized accounting systems are important to businesses in various ways such as time and cost savings, organization and accuracy, storage and speed and easy distribution of financial information.

\section{- Effective use of RIM Ltd. 's software}

The results reveal that about $97.4 \%$ confirm the effective use of RIM Ltd's software. It is the same case in clients' respondents where a large number (76.1\%) of them agree for this fact. This software lead RIM Ltd to shift from manual accounting system and its shortcomings to computerized accounting Systems and its outcomes.

\section{- Clients satisfaction of RIM Ltd. 's services and products}

In small despite with findings, taken into consideration separately, some characteristics of clients satisfaction in RIM Ltd are most suffering than others in accordance with this ascending order: assurance (69.3\%), reliability (66.9\%), empathy (74\%), responsiveness (77.6\%) and tangibility (83.4\%). RIM Ltd should pay more attention on each one of them in order to improve the quality of services and products to their customers stating with the lowest to the highest characteristic in percentage of satisfaction. These results are in conformity by Parasuram et Al. (1985) who stated ten criteria of service quality used by consumers in evaluating service quality and consolidated them into five broad dimensions of customer satisfaction evaluation in 1988. 


\subsection{Assessment of Financial Performance Indicators in RIM Ltd}

After analyzing the ICT determinants in RIM Ltd, the study intended to assess the impact of ICT Utilization on financial performance of microfinance institutions in Rwanda by analyzing the RIM Ltd.'s indicators of financial performance before and after ICT utilization.

\section{- Loan portfolio or portfolio quality ratios analysis}

The findings reveal that RIM Ltd.'s portfolio at risk, measured in terms of non-performing loans (30 days), passed from $3 \%$ in 2011 to $13 \%$ in 2012 , from $13 \%$ in 2013 to $12 \%$ in 2013 , from $12 \%$ in 2013 to $4 \%$ in 2014 and from $4 \%$ in 2014 to $5 \%$ in 2015 . It has been deteriorated since 2012 to 2013 where it reached respectively $8 \%$ and $7 \%$ higher than the BNR accepted threshold (5\%). This deterioration of the loan portfolio affected the profitability of RIM Ltd, as a good portion of its revenues was allocated to provisioning for bad debts. The data show a period trend, with the portfolio quality ratio decreasing from $12 \%$ to $4 \%$ in 2013 and 2014 respectively. This is probably due to more recovery efforts put in by RIM Ltd. from 2014 to 2015, the situation improved tremendously and the trend went positively under the BNR accepted threshold, which is a good index for RIM Ltd. But RIM should conjugate again more efforts to ensure the stability trend. However, to have a good picture of loan portfolio, PaR must be analyzed in conjunction with portfolio at risk and write-offs, since all three are interdependent. This is in conformity with Jansson (2003) who stated the portfolio at risk can have different risk profiles, even if the overall number is the same. A PaR30 of 5\% can be highly risky if it contains a large proportion of loans that are seriously overdue, or it can be relatively safe if loans are sure to be repaid. As for write-offs, they reduce portfolio at risk at the stroke of a pen.

RIM Ltd.'s coverage ratio were jumping from $45 \%$ in 2011 to $31 \%$ in 2012 , from $31 \%$ in 2013 to $40 \%$ in 2013 , from $40 \%$ in 2013 to $30 \%$ in 2014 and from $30 \%$ in 2014 to $36 \%$ in 2015 . This is to mean that in 2011 , only $45 \%$ of the portfolio at risk was covered by 2011 loan loss reserves, only $31 \%$ of the portfolio at risk was covered by 2012 loan loss reserves, only $40 \%$ of the portfolio at risk was covered by 2013 loan loss reserves, only $30 \%$ of the portfolio at risk was covered by 2014 loan loss reserves and only $36 \%$ of the portfolio at risk was covered by 2015 loan loss reserves. The trend varies between $45 \%$ and $30 \%$ of the portfolio at risk with a remarkable efforts in 2011, 2013 and 2015. This is not a positive index for RIM Ltd because its indicator on how is prepared for a worst-case scenario is very lower. This is in agree with empirical studies of CGAP (2004) that argued that, for micro-finance institutions, loan loss reserves usually range between $80 \%$ and $120 \%$ of portfolio at risk. Strong strategies have to be taken here to increase the risk coverage ratio.

From the portfolio quality ratios analyzed, it is revealed that RIM risks an over indebtedness and should double efforts to enhance the robust analysis of repayment capacity and install an incentive systems to prevent over-indebtedness.

\section{- Financial efficiency and productivity ratios analysis}

Operational expense ratio as an indicator of efficiency of RIM Ltd. This ratio highlights personnel and administrative expenses relative to the loan portfolio over the period of study (2011-2015).

The rate of operating expenses on the average gross loan Portfolio was $43 \%$ in $2011,35 \%$ in 2012, 48\% in 2013, $60 \%$ in 2014 and 48\% in 2015. This implies that on 100 Rwf of loan portfolio for the year 2011, RIM Ltd made an operating expenses of $43 \mathrm{Rwf}$ while the same amount invested for the same purpose in 2012 made likewise 35 Rwf of operating expense. On $100 \mathrm{Rwf}$ of loan portfolio in 2013, RIM Ltd spent $48 \mathrm{Rwf}$ while on $100 \mathrm{Rwf}$ of loan portfolio in 2014 and 2015, RIM Ltd disbursed $60 \mathrm{Rwf}$ and 48 Rwf of operating expenses respectively. Then, it is revealed that in RIM Ltd was increased its efficiency as it growed its loan portfolio orderly in 2012, 2011, 2013 and 2015. The value of operational expense over the period of study was positive except in 2014. This indicates that RIM Ltd spent relatively well its operating expense with an exception of 2014, where RIM Ltd realized an operating expense ratio of $60 \%$ over than the BNR accepted threshold of 50\%.

RIM Ltd is efficient but at a non-satisfied degree, because the ratio is too high as well as, for this indicator, the lower the ratio, the more efficient the MFI is. This findings are in range with CGAP (2009) that stated that operating expense ratio is the most commonly used efficiency indicator which enables managers to compare quickly administrative and personnel expenses to the MFI's yield on the gross loan portfolio. Monitoring this trend is an easy way to observe if the MFI is increasing its efficiency as it grows its loan portfolio.

The number of active clients on the number of personnel was 239 in 2011, 259 in 2012, 186 in 2013, 179 in 2014 and 295 in 2015. This implies that the lower number of overall productivity of the RIM Ltd.'s personnel in terms of managing clients, including borrowers, voluntary savers, and others clients was 179 in 2014 awhile the higher number was 295 in 2015. Even though this ratio is determined by others internal issues such as excess paperwork or procedures, 
or external factors, the results revealed that in 2015, 2012 and 2011 RIM Ltd.'s staff members worked hard while in 2014 and 2013 they served a low number of borrowers. A high number of borrowers which explains a positive trend in this productivity ratio is always desirable. These results are in convenience with empirical studies of Jansson (2003) who stated that MFIs use many different efficiency and productivity indicators for tailoring them to reflect their own organizational structure, product lines, and monitoring priorities.

\section{- Financial sustainability and profitability ratios analysis}

The operational self-sufficiency is an indicator of sustainability of RIM Ltd over the period of study (2011-2015). From findings, the rate of operating revenues on the average operating costs was $123 \%$ in $2011,116 \%$ in $2012,102 \%$ in 2013, $98 \%$ in 2014 and 103\% in 2015. This implies that in 2011, 2012, 2013 and 2015, RIM Ltd was, regardless its capital base composition, sufficient to cover its cost of operations with its revenue from operations as well as its operational self-sufficient ratios were above 100\%, the breakeven point. However, in 2014, RIM Ltd was insufficient because its operational self-sufficient ratios were below $100 \%$ which indicates that it did not generate profits. RIM Ltd has to increase its operating revenues and decrease its operating costs in order to improve its ability of operational self-sufficiency. Otherwise, its financial sustainability is low. This results are in conformism with empirical studies of CGAP (2004) that stated that operational self-sufficiency measures how well an MFI can cover its costs through operating revenues.

Return on assets (ROA) as an indicator of profitability of RIM Ltd over the period of study (2011-2015). From findings, the rate of return on the average assets was $5 \%$ in $2011,5 \%$ in $2012,0.55 \%$ in $2013,-1 \%$ in 2014 and $1 \%$ in 2015 . This implies that 100 Rwf invested by RIM LTD in assets for the year 2011 generated 5 Rwf while the same amount invested for the same purpose in 2012 generated also $5 \mathrm{Rwf}$ as net profit after tax. The $100 \mathrm{Rwf}$ invested in total assets generated 0.55 Rwf as net profit after tax in 2013 while 100 Rwf invested in assets in 2014 generated -1 Rwf and 1 Rwf in 2015 as net profit after tax.

The value of ROA over the period of study was positive except in 2014. This indicates that RIM LTD considered in itself, used well its assets to generate returns in 2011, 2012, 2013 and 2015. In these years, RIM Ltd had a positive ROA, then was profitable and also sustainable, because it was covering all its costs and was able to capitalize itself for growth. In 2014, RIM Ltd was neither profitable nor sustainable because it realized a negative ROA of $-1 \%$. This negative ROA was improving in 2015 of $1 \%$, which means that RIM Ltd is not yet profitable but is moving towards it. But from the industry perspective, ROA of $5 \%$ are considered desirable. Then, considering this BNR benchmark, the results predicts that RIM Ltd had an ROA below the industry average in two first years only (2011 and 2012). The findings indicate also that in the others successive years from 2013 to 2015, RIM Ltd was not competitive compared to other bank in the same sector of activity considering that the ROAs were below $5 \%$ over the period of study. These results show a big task to RIM Ltd to generate a return that would meet national microfinance standards or the standards necessary for banks to think it is a good credit risk. The results show also that the investment in ICT did not impact effectively on ROA which is explained by the low investment made by RIM in ICT.

Finally the Return on Equity (ROE) is an indicator of profitability of RIM LTD over the period of study (2011-2015). The rate of return on the average equity was $31 \%$ in $2011,20 \%$ in $2012,2.4 \%$ in $2013,-2 \%$ in 2014 and $4 \%$ in 2015. This implies that 100Rwf invested by shareholders in Equity capital generated 31 Rwf in 2011, 20 Rwf in 2012, 2.4 Rwf in 2013, -2 Rfw in 2014 and $4 \mathrm{Rfw}$ in 2015 as net profit which returns on shareholders' equity. Moreover If an MFI has a positive ROE, then the MFI is profitable and is also sustainable, because it is covering all its costs and is able to capitalize itself for growth. From these findings, the value of ROE over the period of study was positive except in 2014. This indicates that RIM Ltd was able to generate a profit in 2011, 2012, 2013 and 2015. In these years, RIM Ltd had a positive ROE, then was profitable and also sustainable, because it was covering all its costs and was able to capitalize itself for growth. In 2014, RIM Ltd was neither profitable nor sustainable because it realized a negative ROE of $-2 \%$.

Although, the deep analysis lead us to conclude that the ROE ratio shows that even if RIM Ltd was four time profitable and sustainable, the extent of its profitability and sustainability remains insufficient and at a low level because the desirable ROE in banking sector is stated between 12-15\%. For RIM Ltd, this range of the value of ROE were performed only in two first years of our study (2011 and 2012). Otherwise, the results of the others years were less than the industry benchmark indicating that RIM Ltd generates less profit compared to the others industry operators. These results are in conformity with empirical studies of CGAP (2004) who stated ROA and ROE as two most used financial tools to measure how well the MFI uses its assets to generate returns and how well it uses its equity to generate returns for the period.

To conclude, the study states that the results show that the investment in ICT did not impact effectively on those 
financial performance indicators of 5 last years (2011-2015). This should be explained by the low investment made by RIM in ICT in these years as seen above.

\section{- Analysis of influence of ICT on financial performance indicators of RIM Ltd}

From findings, RIM Ltd, portfolio quality or loan repayment, financial efficiency and productivity, financial profitability and sustainability are the financial performance indicators influenced by ICT utilization. $94.7 \%$ confirmed that fact while $5.3 \%$ of respondents agree that none of them is influenced by ICT. Therefore, these financial indicators are not influenced by ICT at the same level! For the staff respondents, the ICT impacts firstly on financial sustainability and profitability $(65.8 \%)$, secondly on financial efficiency and productivity (23.7) and thirdly and finally on portfolio quality (5.3\%). This is in conformity of empirical studies conducted by Kimata (2013) who established that ICT adoption is a major contributor to financial performance of deposits taking saccos.

\subsection{Relationship between ICT Utilization and Financial Performance in RIM Ltd}

After analyzing the ICT determinants in RIM Ltd and the RIM Ltd.'s indicators of financial performance before and after ICT utilization, the study intended to measure the relationship between the determinants of ICT utilization and financial performance indicators of RIM Ltd.

\section{- Comparison of the situation before and after ICT utilization in RIM Ltd}

After comparing the situation before and after ICT utilization in RIM Ltd, about $\mathbf{1 0 0 \%}$ of all staff respondents agree that actually, ICT utilization have a high influence to the RIM Ltd.'s financial performance compared to the previous situation (without ICT utilization). Likewise, 99\% of clients' respondents confirm that option. These results are agreed by Kamau (2014) who carried out a study on the effect of ICT adoption on the financial performance of microfinance institutions in Kenya and concluded that there was a positive correlation between ICT adoption and financial performance of MFI's.

\section{- ICT utilization and financial performance determined by financial profitability and sustainability in RIM Ltd}

About $98.9 \%$ clients' respondents consider strong positive, the impact of ICT utilization on financial performance of RIM Ltd. It's the same in staff respondents where $100 \%$ of them confirm this option. Moreover, to verify this relationship between ICT and financial performance of RIM LTD, the study used a multiple regression analysis whereby the coefficient of determination and the coefficient of correlation were obtained and interpreted. The following tables display the model summary, the coefficients of this regression analysis and the correlation between ICT (X) and financial performance (Y) of RIM Ltd.

Table 1. Model Summary

\begin{tabular}{lllll}
\hline Model & $\mathrm{R}$ & R Square & Adjusted R Square & Std. Error of the Estimate \\
\hline 1 & $.502^{\mathrm{a}}$ & .252 & .136 & 1.15368 \\
\hline
\end{tabular}

a. Predictors: (Constant), Clients satisfaction indicators, Digital financial services, Internet banking accessibility, Branch networking, Software and computerized accounting system

Results provide both the coefficient of determination $\left(R^{2}\right)$ and the coefficient of correlation (R). The coefficient of determination $\left(\mathrm{R}^{2}=0.136\right)$ explained the explanatory power of the model and indicates that $13.6 \%$ of variation in the financial sustainability and profitability of RIM LTD is being explained by the variation in the explanatory variable such as internet banking accessibility, branch networking, digital financial services, software and computerized accounting system and clients satisfaction indicators. The results show that internet banking accessibility, branch networking, digital financial services, software and computerized accounting system and clients satisfaction indicators positively predict the variation on financial performance of RIM ltd as adjusted R Square equal to 0.136 which means $13.6 \%$ the independent variable (ICT) predict the variation of dependent variable (financial performance of RIM ltd expressed by financial sustainability and profitability in the model). However, the $\mathrm{R}^{2}$ of $13.6 \%$ indicates that there are other important variables that affect the financial sustainability and profitability of the RIM Ltd which are not captured by the model formulated in the study that account for about $76.4 \%$ variation not explained by the model. This great portion of variation is due likewise on the fact that RIM Ltd invested lowly in ICT utilization. The coefficient of correlation $(\mathrm{R}=0.502)$ is greater than 0.5 but is around this value. This indicates 
that there is a positive and moderate relationship between ICT utilization and financial sustainability and profitability of RIM LTD.

These findings are close with the findings of Musa et Al., (2012 in their study to assess the impact of investment in information and communication technology on performance and growth of microfinance institution in Uganda. Using two level growth models this study indicated that about $18 \%$ variation in performance and $19 \%$ variation in growth across firms were due to investment in information and communication technologies.

The model equation as indicated by table above become

$\mathrm{Y}=0.094+0.251 \mathrm{X}_{1}+0.072 \mathrm{X}_{2}+0.014 \mathrm{X}_{3}+0.225 \mathrm{X}_{4}+0.544 \mathrm{X}_{5}$

The results tabulated above indicate that all (B) values are positive which means that there is positive relationship between ICT utilization and financial performance determined here by the financial profitability and sustainability of microfinance institutions specifically in RIM Ltd. That means the existence of a proportion of change of financial profitability and sustainability of RIM Ltd that results in the change of one of the predictors specified for the model.

From this table 19, it is shown that the coefficient of internet banking accessibility shows a positive relationship with the financial performance indicators represented by financial sustainability and profitability. Internet banking accessibility of 0.251 indicating that a slight change in new input in internet banking access will increase the financial performance by approximately 0.251 .

Accordingly, the coefficient of branch networking of 0.072 indicates a positive relationship with the RIM Ltd.'s financial profitability and sustainability. The value of $b=0.072$ shows that an increased percentage in branch networking of the RIM Ltd generates an increase in the values of the financial sustainability and profitability by 0.072 units when this ICT determinant is employed alone. The coefficient of digital financial services of 0.014 indicates a positive relationship with the RIM Ltd.'s financial performance. The value of $b=0.014$ shows that an increased percentage in digital financial performance of the RIM Ltd generates an increase in the values of the financial sustainability and profitability by 0.014 units when this ICT determinant is employed alone. The coefficient of software and computerized accounting system of 0.225 indicates a positive relationship with the RIM Ltd.'s financial performance. The value of $b=0.225$ shows that an increased percentage in software and computerized accounting system of the RIM Ltd generates an increase in the values of the financial sustainability and profitability by 0.225 units when this ICT determinant is employed alone. The coefficient of clients' satisfaction indicators of 0.544 indicates a positive relationship with the RIM Ltd.'s financial performance. The value of $b=0.544$ shows that an increased percentage in clients satisfaction of the RIM Ltd generates an increase in the values of the financial sustainability and profitability by 0.544 units when this ICT determinant is employed alone.

The study reports the existence of positive but weak association and insignificant course and effect between ICT utilization and financial performance of RIM Ltd. The strength of the impact is positively moderate due to the low investments made by RIM Ltd in ICT usage. This strength could improve when RIM Ltd decides to invest more in ICT utilization.

The results tabulated above indicate that all (B) values are positive which means that there is positive relationship between ICT utilization and financial performance determined here by the financial profitability and sustainability of microfinance institutions specifically in RIM Ltd. That means the existence of a proportion of change of financial profitability and sustainability of RIM Ltd that results in the change of one of the predictors specified for the model.

From this table 19, it is shown that the coefficient of internet banking accessibility shows a positive relationship with the financial performance indicators represented by financial sustainability and profitability. Internet banking accessibility of 0.251 indicating that a slight change in new input in internet banking access will increase the financial performance by approximately 0.251 .

Accordingly, the coefficient of branch networking of 0.072 indicates a positive relationship with the RIM Ltd.'s financial profitability and sustainability. The value of $b=0.072$ shows that an increased percentage in branch networking of the RIM Ltd generates an increase in the values of the financial sustainability and profitability by 0.072 units when this ICT determinant is employed alone. The coefficient of digital financial services of 0.014 indicates a positive relationship with the RIM Ltd.'s financial performance. The value of $b=0.014$ shows that an increased percentage in digital financial performance of the RIM Ltd generates an increase in the values of the financial sustainability and profitability by 0.014 units when this ICT determinant is employed alone. The coefficient of software and computerized accounting system of 0.225 indicates a positive relationship with the RIM Ltd.'s financial performance. The value of $b=0.225$ shows that an increased percentage in software and computerized accounting system of the RIM Ltd generates an increase in the values of the financial sustainability and profitability 
by 0.225 units when this ICT determinant is employed alone. The coefficient of clients' satisfaction indicators of 0.544 indicates a positive relationship with the RIM Ltd.'s financial performance. The value of $b=0.544$ shows that an increased percentage in clients satisfaction of the RIM Ltd generates an increase in the values of the financial sustainability and profitability by 0.544 units when this ICT determinant is employed alone.

The study reports the existence of positive but weak association and insignificant course and effect between ICT utilization and financial performance of RIM Ltd. The strength of the impact is positively moderate due to the low investments made by RIM Ltd in ICT usage. This strength could improve when RIM Ltd decides to invest more in ICT utilization.

The results are agreed by Kipesha (2013) who studied the impact of ICT adoption on efficiency and financial sustainability of MFI's in Tanzania. He found the correlation results imply ICT usage has a positive impact on efficiency and sustainability as they move in the same direction. He conclude the strength of the impact was found to be low investments in ICT among Microfinance Firms.

\section{Conclusion and recommendation}

\subsection{Conclusion}

This study analyzed the impact of ICT utilization on the financial performance of microfinance institutions in Rwanda with case study of Réseau Interdiocesain de microfinance (RIM) Ltd. It was carried out for the period from 2011 to 2015. The study did a descriptive survey and used both qualitative and quantitative methods to find out how ICT utilization impacts on financial performance of microfinance institutions in Rwanda. It was carried out on the sample size of 134 respondents selected by purposive sampling technique and simple random sampling technique. It used both primary and secondary data collected using questionnaires, interviews and documentary review. Its hypothesis were verified by regression analysis model using the Statistical Package for Social Sciences (SPSS 16.00).

After all, the study found that ICT has been introduced and used in RIM Ltd about 5 years and above. Among five determinants of ICT in the study (internet banking accessibility, branch networking, digital financial services, software and computerized accounting system and clients 'satisfaction, the study reported that only software and computerized accounting system and branch networking are the most used determinants of ICT in RIM Ltd. Although, clients'satisfaction is likewise highly significant in RIM Ltd. All determinants of dependent variable (portfolio quality or loan repayment, financial efficiency and productivity, financial profitability and sustainability are the financial performance indicators influenced by ICT utilization but not at the same level! ICT impacts firstly on financial sustainability and profitability, secondly on financial efficiency and productivity and thirdly and finally on portfolio quality. The study reported also on the relationship between the predictor variables ICT determinants and the dependent variable (financial performance). On this, the results confirmed a positive and moderate correlation between ICT determinants and financial performance of RIM Ltd represented in the regression model by financial sustainability and profitability of RIM LTD. With positive coefficients, the findings of the study revealed that ICT usage move in the same direction with the financial performance. Although, the strength of the impact was found to be very low due to the low investments in ICT made by RIM Ltd.

\subsection{Recommendation}

Based on the findings of suggestions of staff and clients respondents of this study, the study suggests that:

1) RIM Ltd should in order to realize the benefit of ICT usage, increase ICT investment levels, increase client base and their overall uses. The higher level usage of ICT would result for RIM Ltd into improved loan portfolio, financial efficiency, productivity, profitability and sustainability as well as its overall performance.

2) RIM Ltd should aggressively upgrade technology and sciences to adapt to customer's requirements by investing in improvement and equipping modern facilities and technology with various functions to adapt to customers' demands in its services and products delivery such as: electronic banking, internet banking accessibility, digital financial services, PC banking, software and computerized account system, online banking, phone banking, home banking, phone banking, ATM, credit and debit card, money transfer services, foreign currency accounts, agent banking system and others.

3) RIM LTD should have, to be more attractive and competitive with regard to interoperability in mobile money payment, the partnership with the MNOs to enable bank account to e-money account transfers for its 
customers.

4) RIM Ltd should to insure fitness, communicability, reliability and security, introduce a suggestion box for the clients and camera system in its all branches and sub branches.

5) RIM Ltd should embark new attractive marketing strategies upon training program for all its operational staff and public awareness to improve the knowledge of information communication technology and its products and services for the performance financial efficiency, productivity, profitability and sustainability.

6) RIM Ltd should overcome and control the actual regular ICT system failure that customers and staff face by introducing the strong software, implementing the new strategies to avoid the lack of wireless which lead to the poor quality services delivery to the customers.

7) RIM Ltd should review its strategies and double efforts to enhance the robust analysis of repayment capacity and install an incentive systems to prevent over-indebtedness, to improve its efficiency and productivity and to certain with a financial stability its profitability and sustainability indicators.

For further readings, the following areas are suggested (a) Impact of ICT utilization on the Breadth of outreach and Depth of outreach of the microfinance institutions in Rwanda (b) The impact of ICT utilization on customer satisfaction in microfinance institutions in Rwanda c) The effect of ICT utilization on the social poverty reduction of microfinance institutions in Rwanda and (d) Impact of ICT adoption on the on intermediation market structure in the microfinance industry in Rwanda.

\section{References}

Agboola, A. (2001). Information and communication technology (ICT) in Banking Operations in Nigeria. An Evaluation of Recent Experiences. Lagos: Obafemi Awolowo University.

Arifujjaman, M. K., \& Rahaman M. A. (2007). Impact of Microfinance on Living Standards. Empowerment and Poverty Alleviation of Poor People: A Case Study on Microfinance in the Chittagong District of Bangladesh (unpublished master thesis). Chicago: Chicago University.

Berger \& Wharton. (2003). The effect of technological investment and performance of commercial banks in Netherlands. Evidence from the banking industry. Journal of Money, Credit, and Banking, 35(42), 141-176.

Bernd, B. (2007). Microfinance and Public Policy: Outreach, Performance and Efficiency. New York: Palgrave Macmillan Publication.

Bidley, D. E. (2000). The impact of ICT Investment on financial performance of manufacturing firms in Ghana. Journal of economic perspectives, 14(4), 3-22 .

BNR. (2015). Annual Financial Stability Report. Kigali.

CGAP. ( 2006). Good Practice Guidelines for Funders of Microfinance.

FAO. (2014). The state of food insecurity in the world. New York: Food and Agricultural Organization of the United Nations.

Freeman, R. E., Harrison, J. S., Wicks, A. C, Parmar, B., \& de Colle, S. (2010). Stakeholder theory: The state of the art. Cambridge: Cambridge University Press. https://doi.org/10.1017/CBO9780511815768

Gelinas, Ulric J., Sutton, Steve G., \& Hunton, James E. (2005). Accounting Information Systems (6th Ed.). Mason: Thomson South Western.

Gustaffsson, A., Johnson, M. J., \& Roos, I. (2006). The effects of customer satisfaction, relationship commitment dimensions, and triggers on customer retention. Journal of Marketing, 69(4), 210-218. https://doi.org/10.1509/jmkg.2005.69.4.210

Kamau, S. K. (2014). The effect of ICT adoption on the financial performance of micro-finance institutions in Kenya (Unpublished MBA Project). Nairobi: University of Nairobi.

Keivin, P., \& Pierre, P. ( 2011). Mobile money: "An overview for global telecommunications operators" (6th ed.). Ernst\&Young Press.

Kimani, M. (2014). The effect of ICT adoption on the financial performance of savings and credit co-operative societies in Nairobi County (Unpublished MBA Project). Nairobi: University of Nairobi.

Kimata, O. N. (2013). Effect of ICT on the financial performance of deposit taking SACCOS in Nairobi County, 
Unpublished MBA Project. Nairobi: University of Nairobi.

Kipesha, E. (2012). Efficiency of Microfinance institutions in East Africa: Data Envelopment Analysis. European Journal of Business and Management, 4(17), 77-88.

Kipesha, E. F. (2013). Impact of ICT utilization on efficiency and financial Sustainability of Microfinance Institutions in Tanzania. International Journal of INterdisciplinary Studies on Information Technology and Business (ISITB), 1(1), 67-82.

Ledgerwood, J. (2000). Microfinance handbook: an institutional and financial perspective. Washington, DC: The World Bank.

Mosley, P. (2001). Microfinance and poverty in Bolivia. Journal of Development Studies, 37(4), 101-132. https://doi.org/10.1080/00220380412331322061

Musa, M., Akodo M., Mukooza, R., Kaliba, M., \& Mbarika R. (2012). Impact of investment in information and communication technology on performance and growth of microfinance institutions in Uganda. Applied econometrics and international development Journal, 12(2), 151-164.

Muteteri N., A. (2015). Electronic banking and financial performance of Commercial banks in RWANDA : A case study of bank of Kigali. Unpublished master thesis. Kigali: School of Business .

Otero, M., \& Rhyne, E. (1999). Microfinance Matures-Opportunities, Risks, and Obstacles for an Emerging Global Industry, "Innovations, Winter and Spring. Cambridge: MIT Press.

Riggins, F. J., \& Weber, D. M. (2016). Impact of ICT on Market Structure in the Microfinance Industry. The African Journal of Information Systems, 8(3), 1-19.

Romney M., B., \& Steinbart, P., J . (2009). Accounting Information Systems (11th Ed.) Arizona : Pearson.

Sehgal, V. (2008). The business of microfinance. Vihaan: Vihaan Networks Limited (VNL).

Zeller, M., Meyer, K., \& Richard, L. (2002). The Triangle of Microfinance - Financial Sustainability, Outreach, and Impact. London: International Food Policy Research Institute. 